\title{
The Relation of Investment Incentives and Inflow of FDI: Case of Developing Countries and Ethiopia
}

\author{
Addisu Hailu Tulu \\ Law and Development Department, Arsi University School of Law, Assella, Ethiopia
}

Email address:

Addislaws2010@gmail.com

To cite this article:

Addisu Hailu Tulu. The Relation of Investment Incentives and Inflow of FDI: Case of Developing Countries and Ethiopia. International Journal of Economy, Energy and Environment. Vol. 6, No. 5, 2021, pp. 98-103. doi: 10.11648/j.ijeee.20210605.13

Received: January 27, 2020; Accepted: July 15, 2021; Published: September 15, 2021

\begin{abstract}
For economic, Social, or foreign direct investment promotion reasons, tax exemptions or incentives are common under tax laws of legal system of different nations. Under Ethiopian stamp duty laws, some areas of foreign investments are exempted from the liability of payment of same; documents that are exempted in accordance with international agreements and conventional treaties approved by Ethiopian government. The objective of this study article is to show the relationship between incentives and foreign direct investment inflows in developing countries and the Ethiopian context. The thesis employs research methodology that follows conceptual and legal analyses and interpretation in a comparative manner. The meaning and nature of investment incentives under Ethiopian investment laws and other jurisdiction, determinant factors driving and influencing the inflows of FDI under developing counties and Ethiopia are discussed. The dominant model of low income countries/developing countries investment incentive i.e. tax exemption and tax holiday's contribution and effectiveness in the attracting of FDI, and various economics researchers findings on the relationship between income tax incentives and FDI inflows are critically analyzed with the various laws and Ethiopian investment laws. Finally from the findings of different data we can conclude that weak investment climate cannot back up by providing tax incentives to attract FDI in developing countries and Ethiopia. The findings of the study revealed that tax incentive packages that are employed to attract FDI in developing countries are not in a position to accommodate and fulfill the comprehensive driving factors of the FDI and the interest of investors and host states.
\end{abstract}

Keywords: Foreign Direct Investment, Developing Countries, Investment Incentives

\section{Introduction}

Given many developing countries including Ethiopia is striving to economic growth through promoting investment. Fiscal incentive is the typical investment incentive for most developing countries and Ethiopia. The definition of investment incentives in developing countries context and the nature of investment incentives in developing countries obviously fiscal incentive are discussed. The relation between fiscal incentives FDI inflows and the effectiveness of tax incentive in promoting investment in developing countries like Ethiopia are critically analyzed. The study gathers different economic researches and analyzes it with different incentive laws. Different text interpretation and factual analysis have been conducted in order to correlate and analyze the relationship between tax incentive and investment flows Structurally, the paper proceeds as follows:
Section One gives the necessary introduction to the concept of investment incentives, looking at the main types of incentives used and particular issues that arise in connection with incentives for foreign direct investment (FDI). Section two looks at the nature of investment incentives and factors influencing foreign direct investment in developing countries and Ethiopia. Section three is the main body of the paper which aims at showing the relationship between incentives and foreign direct investment inflows in developing countries with particular reference to the Ethiopian cases. The last section is the summery; and the writer's conclusion and recommendation.

\subsection{The Definition of Investment Incentives}

Incentives are measures either to increase the rate of return of a particular FDI undertaking, or to reduce its costs or risks. The following are the main types of incentives used [1]. 
Fiscal incentives may include reduction of the standard corporate income tax, tax rate, investment and reinvestment allowances, tax holiday, accelerated depreciation, exemptions from import duties.

Financial incentives include government grants, subsidized credits, government equity and participation

Other incentives, different types of incentives are included [1].

Regulatory incentives include:

1. Lowering of environmental, health, safety or labour standards;

2. Temporary or permanent exemption from compliance with applicable standards;

3. Stabilization clauses guaranteeing that existing regulations will not be amended to the detriment of investors.

Subsidized services; dedicated infrastructure electricity, water, telecommunication, transportation, (a price less than the market), Subsidized Services like sources of finance, implementing and managing projects, carrying out pre investment studies, informant on markets, advice on production process, and marketing techniques, assistance with training and retraining, technical facilities to develop know how,

Market privileges, it includes granting of monopoly rights, protection form import competition, closing the market to further entry, preferential government counteracts. Preferential government contracts; Closing the market to further entry or the granting of monopoly rights; protection from import completion,

Foreign exchange privilege is special treatment with regard to foreign exchange [1].

The Ethiopian government is committed to grant investment incentives to promote the investment objectives [2].

The regulations to be issued should determine the type and extent of entitlement to incentives. Accordingly, the Council of Ministers issued Regulations No 270/2012. The regulations provides for the types and extent of investment incentives [3].

Exemption from the Payment of Customs Duty; the investor is allowed to import to Ethiopia capital goods and construction materials that are "necessary for the establishment of a new enterprise or for the expansion or upgrading of an existing enterprise. The main purpose of such an incentive is to encourage the investor to establish an enterprise to invest or to upgrade the already existing enterprise to invest or to upgrade the already existing enterprise. Hence, necessary capitals and materials are allowed to be imported without paying custom duty [3].

Exemption from tax; the general principle is that everybody who accrues income should pay an income tax. However, an investor may be eligible for exemption from income tax. An investor who is engaged in manufacturing, or agro-industrial activities, or the production of agricultural products that are to be determined by directives issued by the board is eligible [3]. In addition to invest in the aforementioned sectors of the economy, an investor should export at least $50 \%$ of his/her products, or if $\mathrm{s} /$ he is not directly involved in export, s/he should supply $75 \%$ of his/her products to an exporter as a production input. We have seen that investment is a business activity, so an investor is duty bound to pay income tax.

\subsection{The Nature of Investment Incentives in Developing Countries}

The general rule is that developed countries make more use of fiscal incentives than financial ones [4]. This is justified by the fact that fiscal incentives are less flexible and countries need to pass through more difficult parliamentary procedures to adopt them. On the other hand, developing countries adopt the reverse, that is, they adopt fiscal incentives because they lack the resources needed to provide financial incentives.

Incentives are a policy tool in the global competition to attract FDI and benefit more from it. Incentives can be successful only where they can attract investment irrespective of their rationale. In the era of open market world economy, each country competes through incentives to drive investment away from competing host countries [4]. It is crucial to be competent in every aspect (in the economy, knowhow and technology, etc) to come out successful in the competition to attract investment.

One may ask that does developing country like Ethiopia be successful in attracting investment by means of incentives. This question and the like will be discussed later under the last section of this paper. The bare fact is that the poor countries are relatively disadvantaged in the game of competition for FDI [4].

The other issue that has to be addressed is, if governments may see tax incentives as a necessary measure to compete with other countries, and to signal government commitment to an open investment environment [5]. Support for incentives could also arise from agency problems and the comparative ease with which incentives can be enacted [5]. In most instances however, the efficacy of these measures are overestimated while the costs remain hidden [5].

The legal instruments granting tax incentives have to bedrafted carefully so that they achieve policy objectives with a minimum leakage of tax revenue. They are expressed as precisely as possible so as to avoid the need for frequent corrections or changes. It is believed that frequent changes could contribute to the perception that the tax system is complex and difficult to comply with [5]. Apart from the tax incentives regime, stability and predictability of the tax system are major factors influencing firms when they commit to long term investment.

Apart from revenue losses, they include distortions to the economy as a result of preferential treatment of investment qualifying for incentives, administrative costs from running and preventing fraudulent use of incentives schemes, and social costs of rent-seeking behavior, including possibly an increase in corruption. Excessive use of tax incentives complicates administration, facilitates evasion, and 
encourages corruption [6]. It also costs businesses time and money to comply with audit requirements..

In Ethiopia one of the greatest benefits offered by Ethiopian government to attract investment in the country, especially Foreign Direct Investment is tax incentive. In this facilitation service, EIC works hand in hand with Ethiopian Revenues and Customs Authority (ERCA) to secure tax/duty free benefits to investors depending on their field/industry involvement. Currently EIC is implementing an investment incentive management systems; the new CRM system is expected to interface with the investment incentives management system via Web Services [7].

Assessing the relative advantages and disadvantages of tax incentives is a complicated and controversial issue. Investment is indeed the result of incentives. Because it's recognized that incentives are not the prime determinant of investment decisions, what are the dominant determinant of investment inflow are discussed below.

\section{Factors Influencing Foreign Direct Investment Inflows in Developing Countries and Ethiopia}

Most Economics researchers have examined this issue almost for forty (40) years and the following three points have been forwarded as reasons for foreign investment. The first reason is that multinational companies own assets that can be exploited on a large scale, organizational and managerial skills, and marketing net works. Secondly, the profit that could be gained from investing abroad is greater than that could be gained from the home country. Thirdly, investors decide to undertake foreign direct investment (FDI) where it is preferable to licensing the production [8]. There are also economic factors that determine the FDI. They are;

Market-seeking-FDIs are made in seeking market for goods and services;

Resourcelasset seeking-investors require resources or assets to produce, and therefore, they will invest in locations where resources or assets are available;

Efficiency seeking is another factor stimulating foreign direct investment. Thus investors will undertake investments where the production is efficient in terms of cost [8].

D) Transportation costs-it becomes unprofitable to ship some products a long distance when transportation costs are added to production costs.

In developing countries, the trend is that both inflows and outflows rose in 2005 although trends varied by regions. According to the study conducted by the UN, inflows into and outflows from Latin America and the Caribbean and West Asia rose in 2005. But, only inflows rose in Africa and East, south and South- East Asia in the same year. West Asia underscored both inward and outward [9].

In Africa, rising corporate profits and high commodity prices helped boost inflows in 2005 to $\$ 31$ billion from $17 \$$ billion in 2004 . However, the region's share of global FDI remained at around 3\%. The inflows concentrated in mining, in particular oil and gas, although there was also investment in services from the United Kingdom, the United States, South Africa, China, Brazil and India. With respect to manufacturing, low skill labour, fragmented markets and lack of diversification inhibited FDI in Africa [9]. South Africa, Egypt, Nigeria, Morocco and Sudan accounted for $66 \%$ of the region's FDI inflows in descending order of value of FDI in 2005. South Africa, Egypt, Nigeria, Morocco and Sudan accounted for $66 \%$ of the region's FDI inflows in descending order of value of FDI in 2005 [9]. Investment from China and other Asian economies increased particularly in the oil and telecom industries [9].

FDI inflows into East Africa fell to \$ 1.7 billion from $\$ 1.9$ billion in 2004 , which represented only $5 \%$ of the inflows to Africa. Two factors are pointed out as reasons for the decline in the inflow of FDI in East Africa. These concern the fact that the sub-region is poor in resources, and there is a political instability. As a result the inflow of FDI into Ethiopia, Kenya, Madagascar and Mozambique declined in 2005. On the other hand Uganda attracted more FDI due to its continued macro economic and political stability [9].

Foreign investors are encouraged by several factors to invest abroad in general and in a developing country in particular. There are also factors that pull investors to invest abroad. These factors may be categorized as pull factors and push factors. Pull factors are factors that attract the investor towards developing countries to invest. Push factors, on the other hand, are unfavorable factors in the home state of the investor that repel the investor from that country. Thus, push factors have the force to push the investor to opt for a favorable condition to invest in. Therefore, the investor will go to abroad to invest. It is worth noting that push factors are the opposite of pull factors.

Market pull factors, investors need market for their production.

Now a day, the world is divided into different economic blocks. For example, there are the common Market of Eastern and Southern Africa (COMESA), European Union (EU) etc. If the product originating from a member country of a block, it may benefit from preferential tax treatment compared to a similar product originating from another region. For example, a product originates from Ethiopia will get a preferential tax treatment in COMESA than a similar product that originated from China because Ethiopia is a member to COMESA while China is not. Thus, if the particular product has a demand in COMESA, Chinese investor may want to invest it in Ethiopia to be a beneficiary of the COMESA [10]. Market pull factors are the most important determinants of FDI especially in host economies. Large Markets that are emerging in developing countries will be more attractive. However, the size of the market depends on the type of the product. Thus, the capacity of the consumers to buy the product is crucial [9].

Resources: An investor needs natural and human resources in a reliable manner to produce or manufacture. Thus, the investor could be attracted by the abundance of natural and human resources available in developing countries. An 
investor will prefer to invest in a country where natural resources needed for the manufacture of his/her/its produce are available in a large quantity and at a cheaper in price [9]. In addition, an investor will be attracted to invest in a country where skilled, disciplined and cheap labour force is found; other factors being equal [9]. Policy frameworks of a host country also determine the direction of FDI. Liberalized economic policies and privatization policies of a host country attract FDI. Regulations and inducements encouraging FDI and investment treaties (bilateral or multilateral) facilitating FDI are pull factors [9]. Political and economic stability: Investors are investing with a view to gaining profit which would be realized through time. Thus, to gain profit, the political and economic stability of a country are essential. Therefore, investors will be attracted to invest in a country where there is political and economic stability.

Existence of relevant clusters:- The nature of investment requires the existence of some inputs from other enterprises. A group of enterprises feeding each other within put are known as a cluster.

For example, a textile factory needs an enterprise that spins cotton and produces raw material to produce clothes. An investor will be attracted to invest in a country where inputs are available for him/her/it to produce.

Growth: An investor wants to invest in a country where there is a demand for the product because this may reduce cost to transport the product to such country by producing it in the country. This definitely will increase the profit from the investment. Investing in the country where there is demand for the product will also enable the investor to adapt the product to local needs and taste. The point here is that the foreign investor prefers to invest in the country if customers of a given product grow in number, the other factors being same.

Lax Environmental Laws -Developed states require investors to ensure that their investment does not affect the environment negatively. For example, they may require investors to reduce their carbon emission to a specified level. In short, the investment law of developed states is very strict in protecting their environment. On the other hand, developing countries have less strict laws in this regard. Consequently, investors would invest in developing countries to reduce additional costs due to strict environmental law [9].

\section{The Relation of Investment Incentives and Inflow of FDI in Developing Countries and Ethiopia}

In previous the sections of this paper, we had the bird's eye view of the nature and factors influencing FDI. Now let us see how FDI inflows and investment incentive in developing countries and in Ethiopia are related.

Does the weak investment climate be backed up by providing incentives to attract FDI in developing countries and Ethiopia?

What is important is to note that different incentives may attract different investors. For example, the export-oriented investors seeking inexpensive labour give more value to fiscal incentives than market protection or other incentives [11]. On the hand, market-seeking investors a value market protection more than fiscal incentives. Thus, it is important to consider different incentives to attract investors. Natural resource seeking investors show low responses to incentive because what drives FDI is primarily not driven by tax incentive rather non tax factors. Market seeking FDI also shows low response to incentive because the factor driving FDI is level of playing field between field systems for all. On the other hand strategic asset seeking FDI is also have low response for incentive because FDI is driven by location of asset however lower taxes on capital gains reduces the cost of transfer of the asset. However efficiency seeking FDI shows high response to tax incentives because it's driven by tax incentive factors. Firms are expected to compete globally hence the lower the costs the better their ability to compete globally [12]. In general, incentives play a role in attracting investment even though they do not rank high among the main FDI determinants [4]. The bare fact is that the poor countries are relatively disadvantaged in the game of competition for FDI. It is crucial to be competent in every aspect in the economy, knowhow and technology, etc to come out successful in the competition to attract investment [4]. In developing countries incentives are said to play a relatively minor role influencing decisions about investment compared with "market size and growth, production costs, skill levels, adequate infrastructure, economic stability and the quality of the general regulatory framework." Hence, the decision of FDI inflows is made mainly on the basis of economic and long term strategic considerations concerning inputs, production costs and markets as discussed above in section three, (emphasis added) [4]. These factors being equal, incentives play a great role in attracting investment.

Different economic researchers in different jurisdiction tried to show the relationship between tax incentive and FDI inflows.

Falmi (2012) carried out a study to analyze the relationship between tax holiday and foreign direct investment in Indonesia tax holiday regulation from 1958-2010 and also analyzed weather it affected the FDI trend during the study period. The results of the study revealed that; during the Soekarno regime, inconsistency in the implementation of tax holiday was experienced creating uncertainty among investors. Furthermore, during the Suharto regime, investors were skeptical in extending tax holiday facility since there were no comprehensive measures to select which investors were qualified to be taken tax holiday. One of the main conclusions of the study was tax holiday being the main objective of the study was credibly verified not significant as determinant of the FDI inflows. Apparently this is because Indonesian tax holiday incapable of counter balancing economic, politic, government policy susceptibility as well as poor infrastructure like it once prevailed in this country. Also where investors' investment decision making is concerned, tax incentives and specifically tax holiday is not a major 
consideration. Nevertheless tax holiday happens to be an extra advantage for investors in locating their firms if other main determinants of FDI are available [13].

Research conducted by Massoud (2003) on inflows of Egypt FDI concluded that;

"The policies in the country should mainly focuson obtaining macroeconomic related benefits from FDI rather than concentrating on the ones that attract FDI. The study further stated that the need to improve the sufficient qualified labour while focusing sound institutions establishment as well as international trade introduction will enable potential investors to find the country more favourable due to its location characteristics [14]."

This study implies those tax incentive packages that areemployed to attract FDI in developing countries are not flexible enough so as to accommodate and fulfill the comprehensive driving factors of the FDI and the interest of investors and host states.

Research conducted in Kenya (Francis Bakumbi, 2017) reveals that;

"Even though the research findings has proved tax incentives have an impact of FDI inflows of multinational corporations in Kenya, analysis of percentage change in FDI inflows from 1995-2015 contradict the results. An insignificant range -001\%- 0.58 was observed, which shows FDI inflows are affected by other factors from tax incentives. Probably this could be social, security and political stability of the investment destination [4]." From the research quotation we can assume that the availability of tax incentive alone cannot guarantee the significant inflow of FDI, so the availability of political stability and security is a precondition for the healthy flow of FDI.

Previous research that examined effects of tax incentives on investments in OCED countries by analyzing existing literature and case studies concluded that tax incentives alone are unlikely to increase or attract investments [4]. The study key findings indicated that both costs and benefits are derived from every tax incentive. The increased investments determine the benefits where as the revenue losses by the government determine the costs. Therefore, the study recommended that in order to monitor costs and benefits of tax incentives, government should always prepare expenditure statements.

In Ethiopia one of the study conducted, (Mistre Damtew, 2014) revealed that;

"Data's from EIA Investment has shown remarkable growth status within the last 20 years. The investment determinant factors mostly depend on the non tax factor than tax factors and investors invest in Ethiopia for three reasons. The first one is in search of available market for their products market through investment rather than export. The second is efficiency seeking that's to benefit from the low labor cost or in search of natural resources available in the country but not being attracted to the fiscal incentives. The major obstacle of investment mentioned is infrastructure.

The other is the availability of utility; water, electricity, and road and telecommunication service is basic necessity in operating a business. Economic and political stability, production and work costs, qualified labor force, infrastructure, industry tradition, low costs, and development of the country are the major determinants of FDI inflows and the study indicated weak investment climate cannot be backed up by providing incentive [5]."

So the data analyzed dictates if the government assures low taxes and maintains stability in the country, it will be favorable for investors without any investment incentives. The study further recommended that government should protect the economy byavoiding grey economic areas such as tax evasion. When incentives are provided it is essential to ensure that it's based on rules and those benefiting from incentives file tax returns and face audits that governments produce tax expenditure statements so that the cost of incentives is transparent, and those incentives are occasionally reviewed for their efficacy. The study showed that with lenient and less transparent tax system it's difficult to establish effective tax incentive that attracts FDI inflows.

\section{Conclusion}

Different empirical quantitative economic discipline researches provide us that the nature of developing countries investment incentive alonecannot defeat the FDI inflows. Incentives play a role in attracting investment even though they do not rank high among the main FDI determinants.

Developing countries are relatively disadvantaged in the game of competition for FDI. It is crucial to be competent in every aspect in the economy, knowhow and technology, etc to come out successful in the competition to attract investment. In developing countries incentives are said to play a relatively minor role influencing decisions about investment compared with "market size and growth, production costs, skill levels, adequate infrastructure, economic stability and the quality of the general regulatory framework etc. FDI inflows are made mainly on the basis of economic and long term strategic considerations concerning inputs, production costs. These factors being equal, incentives play a great role in attracting investment. Different incentives may attract different investors. The export-oriented investors seeking inexpensive labour give more value to fiscal incentives than market protection or other incentives. On the hand, marketseeking investors a value market protection more than fiscal incentives. Natural resource seeking investors show low responses to incentive because what drives FDI is primarily not driven by tax incentive rather non tax factors. Market seeking FDI also shows low response to incentive because the factor driving FDI is level of playing field between field systems for all. On the other hand strategic asset seeking FDI is also have low response for incentive because FDI is driven by location of asset however lower taxes on capital gains reduces the cost of transfer of the asset. However efficiency seeking FDI shows high response to tax incentives because it's driven by tax incentive factors. Firms are expected to compete globally hence the lower the costs the better their ability to compete globally. Therefore those tax incentive packages that are employed to attract FDI in developing 
countries are not flexible enough so as to accommodate and fulfill the comprehensive driving factors of the FDI and the interest of investors and host states. Therefore we can conclude that weak investment climate cannot back up by providing incentives to attract FDI in developing countries and Ethiopia.

\section{References}

[1] Aron Mijumdor, (2006) "Ethiopian Investment Incentives in the Light of International Investment Law", Ethiopian Journal of Business \& Development, Unity University College, United Nations, International Investment Agreements: Key Issues, volume II, 2004.

[2] Ethiopian Investment Proclamation no. 769/2012, art. 23.

[3] Ethiopian Investment Regulation no. 270/2012 art.

[4] United Nations, International Investment Agreements: Key Issues, Volume II, 2004, PP: 53.

[5] Mistere Damtew, (2014) effectiveness of tax incentive in promoting investmentin Ethiopia, p-21.
[6] Klemm, A \& Parys (2009), empirical evidence on effects of tax incentives, IMF Working paper, 09/136 (Washington; IMF).

[7] EIC;(Customer Relationship Management System (CRM) For Ethiopian Investment Commission (EIC) (2017).

[8] Gibrehiwot Ageba (1999). Investment; (Unpublished).

[9] Mark B. Baker, "Awakening the sleeping Giant: India and Foreign Direct Investment in the 21st Century," 15 Indiana International \&Comparative Law Review, 389 (2005).

[10] The 8th Columbia International Investment Conference on Investment Incentives: The good, the bad and the ugly (2013).

[11] Dr. Sebastian James, Effectiveness of Investment Incentives in Developing countries, Evidence and Policy Implications.

[12] Falmi, M. R, (2012). Analyzing the relationship between tax holiday and direct investment in Indonesia.

[13] Massoud, MR (2003). Assessment of FDI incentives in Egypt 0336, Economic research Forum working paper series.

[14] Francis Kabubi, (2017). Relationship between tax incentives and FDI inflows in Kenya. 